\title{
STUDI TIPE BATUAN DAN PEMODELANNYA DI BLOK X, CEKUNGAN BARITO
}

\author{
ZURISMAN FITRIADI, DWIHARSO NUGROHO, NURCAHYO INDRO BASUKI
}

\author{
Program Studi Teknik Geologi, Fakultas Ilmu dan Teknologi Kebumian, Institut Teknologi \\ Bandung (ITB), Jl. Ganesha No.10, Bandung, Jawa Barat, Indonesia, 40132, Email: \\ zuris.adi@gmail.com.
}

\begin{abstract}
Sari - Cekungan Barito adalah cekungan foreland yang berumur Tersier dan terbentuk sebagai akibat dari interaksi Lempeng Pasifik, Paparan Sunda, dan India-Autralia. Reservoir utama Lapangan X adalah Formasi Tanjung yang memiliki beberapa lapisan, namun pada penelitian ini hanya Lapisan D yang menjadi fokus penelitian. Lapisan D terletak di dalam Formasi Tanjung bagian bawah yang diyakini diendapkan pada lingkungan sungai berkelok. Data batuan inti dan sayatan tipis dari sumur X-090, X-104, dan X-105 menunjukkan adanya 9 litofasies, yaitu (1) batulanau-batulempung (F), (2) batulanau berakar (Fr), (3) batupasir sangat halus (Svf), (4) batupasir halus (Sf), (5) batupasir halus bioturbasi dan berakar (Sfbr), (6) batupasir halus semen lemah (Sfwc), (7) batupasir sedang semen lemah (Smwc), (8) batupasir sedang semen sedang (Smmc), dan (9) batupasir kasar (Sc). Kesembilan litofasies tersebut dikelompokkan ke dalam empat fasies arsitektural, yaitu (1) channel sand, (2) point bar, (3) crevasse splay, dan (4) overbank. Pemodelan properti reservoir yang dikontrol oleh model fasies dan tipe batuan menunjukkan hubungan sifat petrofisika terhadap tipe batuannya. Nilai porositas yang tinggi berasosiasi dengan channel sand. Nilai permeabilitas yang tinggi berasosiasi dengan tipe batuan RT 1 dan RT 2. Sementara nilai RT 3 memiliki nilai permeabilitas yang paling buruk.
\end{abstract}

Kata Kunci: pemodelan reservoir, tipe batuan, Lapisan D Formasi Tanjung.

\begin{abstract}
Field $X$ is an oilfield in Barito Basin, South Kalimantan, which produces hydrocarbon from reservoir within Lower Tanjung Formation. The oil discovery in this field was initiated in 1930 by BPM and until now Tanjung field is still productive and field development is ongoing. Layer D is in Lower Tanjung Formation and is believed as meandering channel depositional setting. Core and thin section data from Layer D could be found from well X-109, X-104, and X-105. Analysis which has been conducted finding 9 lithofacies', including (1) siltstone-claystone (F), (2) rooted siltstone (Fr), (3) very fine sandstone (Svf), (4) fine sandstone (Sf), (5) bioturbated and rooted fine sandstone (Sfbr), (6) weakly cemented fine sandstone (Sfwc), (7) weakly cemented medium sandstone (Smwc), (8) moderately cemented medium sandstone (Smmc), and (9) coarse sandstone (Sc). These lithofacies' are grouped into four architectural facies' (1) channel sand, (2) point bar, (3) crevasse splay, dan (4) overbank. Rock type determination used flow zone indicator (FZI) method found 3 rock types (RT). RT 1 is associated to channel sand, RT 2 is associated to channel body, point bar, and overbank, and RT 3 is associated to channel sand, point bar, crevasse splay, and overbank. Reservoir properties modelling which is controlled by facies and rock type models showed relation in petrophysical behaviour to its rock type. High porosity values are associated to channel sand. High permeability values are associated to rock type RT 1 and RT 2.
\end{abstract}

Keywords: reservoir modeling, rock type, Layer D of Tanjung Formation.

\section{PENDAHULUAN}

Lapangan $\mathrm{X}$ merupakan salah satu lapangan minyak dan gas bumi di
Kalimantan. Penemuan minyak pertama kali pada 1930 dan hingga kini lapangan $\mathrm{X}$ masih produktif. 
Reservoir utama Lapangan X adalah Formasi Tanjung, yang merupakan reservoir silisiklastik dan diendapkan pada lingkungan aluvial. Reservoir silisiklastik umumnya memiliki hubungan nilai porositas dan permeabilitas. Namun terkadang satu porositas dapat memiliki beberapa nilai permeabilitas. Hal ini membuat keterkaitan antara porositas dan permeabilitas menjadi sulit diprediksi. Penelitian pada Lapisan D, Formasi Tanjung bagian bawah diperlukan dengan cara menganalisis fasies dan tipe batuan petrofisika serta sebarannya dengan melakukan pemodelan reservoir tiga dimensi.

Cekungan Barito merupakan cekungan tipe cekungan foreland yang mengalami inversi dan berumur Tersier. Cekungan Barito dibatasi oleh Sesar Adang di bagian utara, terpisahkan dari Cekungan Jawa Timur di bagian selatan, berbatasan dengan Pegunungan Meratus di bagian timur, dan dibatasi oleh Paparan Sunda di bagian barat (Kusuma dan Darin, 1989; Satyana dan Silitonga, 1994).

Stratigrafi Cekungan Barito tidak terlepas dari sejarah tektonik yang terjadi. Fase pra-lisu merupakan komplek batuan dasar yang berumur Pra-Tersier. Fase bareng-lisu yang diendapkan pada Paleosen Akhir-Eosen Tengah terdiri dari menyusun Formasi Tanjung bagian bawah. Fase pasca-lisu tersusun oleh Formasi Tanjung bagian bawah dan Formasi Berai, diendapkan pada fase pembebanan regional berumur Eosesn Tengah-Miosen Awal. Fase barenginversi diendapkan pada Miosen Tengah hingga puncaknya pada Plio-Pleistosen yang disebabkan oleh aktivitas pengangkatan Pegunungan Meratus (Satyana dan Sillitonga, 1994).

Formasi Tanjung adalah reservoir utama Lapangan $\mathrm{X}$ yang terdiri dari beberapa lapisan. Lapisan A dan B terletak paling bawah didominasi konglomerat yang terendapkan pada lingkungan sungai teranyam. Lapisan $\mathrm{C}$ terdiri dari sedimen berukuran lebih halus namun terdiri dari dua bagian, Lapisan C bagian bawah memiliki karakteristik mirip Lapisan A dan B, sementara Lapisan $\mathrm{C}$ bagian atas berbutir lebih halus dengan karakter menghalus ke atas, diendapkan sebagai point bar sungai berkelok. Lapisan D umumnya berstruktur silang-siur tabular dan berpola menghalus ke atas dengan kandungan lempung yang semakin meningkat. Lapisan D dianggap endapan sungai berkelok. Letak Lapangan $\mathrm{X}$ ditunjukkan oleh Gambar 1.

Konsep reservoir quality index (RQI) dan flow zone indicator (FZI) diperkenalkan oleh Amaefule dkk. (1993) kemudian dikembangkan oleh Abbaszadeh dkk. (1996). Asumsi pada konsep RQI dan FZI adalah bahwa ukuran celah pori sebagai pengontrol karakter petrofisika reservoir. Konsep ini tidak melibatkan proses sedimentasi dan diagenesis saat membentuk celah pori tersebut. Karena hal itu maka batas-batas unit aliran atau tipe batuan tidak selalu sama dengan batas fasies (Abbaszadeh dkk., 1996). Akan tetapi fasies dan diagenesis digunakan kemudian dalam pencarian sebab perbedaan karakteristik aliran fluida yang sudah diidentifikasi (Amaefule dkk., 1993).

Metode RQI dan FZI menggunakan nilai permeabilitas, porositas hasil dari pengukuran batuan inti rutin dan normalized porosity yang merupakan rasio porositas terhadap matriks batuan. Unit RQI dan FZI adalah mikrometer. Sampel batuan yang digolongkan ke dalam tipe batuan yang sama akan memiliki nilai FZI yang tidak jauh berbeda. 


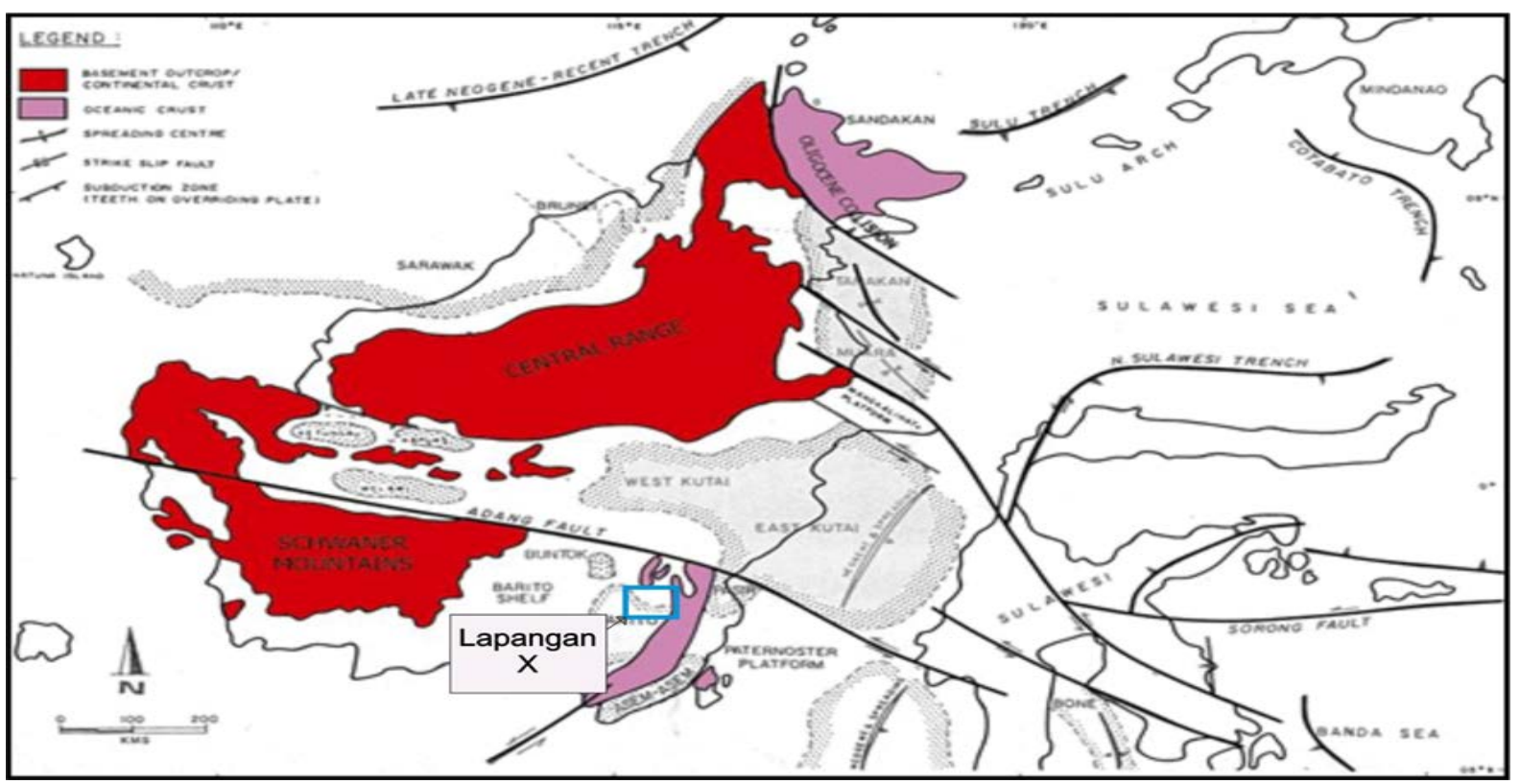

Gambar 1. Peta lokasi penelitian di Lapangan X, Cekungan Barito (Kusuma dan Darin, 1989).

Pembagian nilai-nilai FZI ke dalam satu tipe batuan dengan mengubah nilai FZI ke dalam bentuk discrete rock type (DRT). Perhitungan DRT untuk memudahkan dalam penentuan unit batuan.

\section{METODOLOGI}

Data yang digunakan berupa log talikawat dari 63 sumur, data studi sedimentologi yang berisi informasi sayatan tipis dan batuan inti dari empat sumur, dan data geofisika berupa data seismik.

Tinjauan ulang dilakukan pada data batuan inti dan sayatan tipis untuk mengetahui litofasies dan fasies arsitektural. Informasi analisis batuan inti rutin diolah dalam identifikasi tipe batuan menggunakan metode flow zone indicator (FZI). Salah satu hasil dari metode FZI adalah nilai transformasi porositas-permeabilitas untuk tiap tipe batuan .Log sumur digunakan dalam analisis petrofisika untuk mengetahui volume serpih, porositas, dan saturasi air. Integrasi log sumur dengan hasil interpretasi litofasies dan fasies arsitektural menghasilkan interpretasi elektrofasies.

Data seismik digunakan dalam pemetaan struktur waktu dan kedalaman untuk memberikan gambaran geometri pada daerah penelitian. Integrasi seluruh data yang telah dianalisis dilakukan untuk memodelkan reservoir secara tiga dimensi.

Pemodelan reservoir dimulai dengan memodelkan distribusi fasies sebagai pengontrol penyebaran tipe batuan. Tahap selanjutnya pemodelan petrofisika yang mencakup porositas dan permeabilitas. Pemodelan fasies, tipe batuan, dan porositas menggunakan masukan analisis variogram dalam penyebarannya. Pemodelan sebaran nilai permeabilitas hanya menggunakan transformasi nilai porositas ke permeabilitas hasil analisis tipe batuan yang telah dilakukan sebelumnya.

Peninjauan ulang analisis batuan inti didapati ada 9 litofasies. Sementara hasil tinjauan ulang sayatan tipis didapati sampel tergolong ke dalam sublitharenite dan quartarenite. Hasil analisis elektrofasies menunjukkan terdapat 
empat pola log sinar gamma yaitu bell shape, funnel shape, blocky, dan high gamma yang masing-masing menunjukkan fasies arsitektural yang berbeda.

Hasil analisis tipe batuan menggunakan metode RQI dan FZI menunjukkan adanya tiga tipe batuan, yaitu RT 1 yang mampu mengalirkan fluida paling baik, RT 2, dan RT 3 yang mampu mengalirkan fluida buruk. Tipe batuan memiliki hubungan terhadap fasies arsitektural dan litofasies. RT 1 terdapat pada channel sand. RT 2 terdapat pada channel sand, point bar, dan overbank, dan RT yang terdapat pada channel sand, point bar, overbank, dan crevasse splay.

Pemodelan reservoir yang dilakukan dengan memodelkan fasies, tipe batuan, porositas, dan permeabilitas dengan menggunakan data-data hasil olahan sebelumnya menunjukkan hasil yang cukup baik.

\section{ANALISIS DAN PEMBAHASAN Tinjauan Ulang Batuan Inti}

Proses ini dilakukan dengan menganalisis deskripsi batuan inti dari sumur X-105, X-090, dan X-104 yang memperhatikan ukuran butir, struktur sedimen, sortasi butiran, keterdapatan bioturbasi dan akar, serta kondisi sementasi pada batuan. Deskripsi ini bertujuan menentukan litofasies. Walker dan James (1992) menyatakan bahwa litofasies ditentukan dengan melihat sifat fisik suatu batuan yang dikelompokkan berdasarkan kombinasi litologi, fisika, dan struktur biologi yang membedakannya dari sekelompok batuan di atas, di bawah, dan di samping kelompok batuan tersebut.

Sumur X-105 menunjukkan adanya 8 litofasies, yaitu batulanau-batulempung (F), batupasir halus (Sf), batupasir sangat halus (Svf), batupasir halus bioturbasi dan berakar (Sfbr), batupasir sedang semen sedang (Smmc), batupasir kasar
(Sc), batulanau berakar (Fr), dan batupasir sedang semen lemah (Smwc).

Sumur X-090 menunjukkan adanya 5 litofasies, yaitu batulanau-batulempung (F), batupasir halus semen lemah (Sfwc), batupasir halus (Sf), batupasir sangat halus (Svf), dan batupasir halus bioturbasi dan berakar (Sfbr).

Sumur X-104 menunjukkan adanya 3 litofasies, yaitu batulanau-batulempung (F), batupasir sangat halus (Svf), dan batupasir halus semen lemah (Sfwc). Ketiga sumur tersebut memiliki 9 litofasies yaitu F, Fr, Svf, Sf, Sfwc, Sfbr, Smmc, Smwc, dan Sc.

\section{Tinjauan Ulang Sayatan Tipis}

Proses ini dilakukan dengan menganalisis sayatan tipis dari tiga sumur dengan batuan inti (X-105, X-090, dan X-104). Total sampel yang tersedia berjumlah 7 buah. Lima sampel tergolong quartzarenite dan dua sampel tergolong sublitharenite dengan kandungan kuarsa 85-98\%, litik 1-14\%, dan k-feldspar 0$3 \%$. Bentuk butir menyudut tanggung hingga membundar tanggung. Sortasi sedang hingga baik. Porositas yang berkembang adalah antarbutir dan pelarutan dengan rentang nilai 6-23\%. Tabel 1 menunjukkan deskripsi sayatan tipis.

Porositas pelarutan berhubungan dengan kandungan kaolinit yang cukup banyak di dalam rongga antarbutir. Semen didominasi oleh kaolinit. Sedikitnya kandungan k-feldspar diduga akibat kaolinitisasi yang intensif sehingga terjadi pelarutan butiran k-feldspar dan terjadi presipitasi semen kaolinit.

\section{Identifikasi Elektrofasies}

Proses ini membandingkan hasil analisis batuan inti dengan pola log sinar gamma dari sumur dengan batuan inti yang bertujuan untuk menentukan fasies arsitektural. Log sumur menunjukkan empat pola sinar gamma. 
Pola bell shape menunjukkan nilai sinar gamma yang membesar ke atas yang diinterpretasi sebagai endapan point bar. Pola funnel shape yang menunjukkan nilai sinar gamma yang mengecil ke arah atas diinterpretasi sebagai endapan crevasse splay. Pola blocky yang menunjukkan nilai sinar gamma yang rendah dan konstan ke arah atas diinterpretasi sebagai endapan channel sand. Pola log dengan sinar gamma tinggi dan konstan ke arah atas diinterpretasi sebagai endapan overbank.

\section{Analisis Lingkungan Pengendapan}

Lapisan D Formasi Tanjung merupakan reservoir silisiklastik dengan ukuran butir lempung hingga kasar, kandungan kuarsa yang tinggi, terkadang terdapat akar-akar dan bioturbasi sebagai indikasi endapan darat, pola sinar gamma menunjukkan bell shape secara umum, geometri reservoir hasil pengolahan atribut seismik menunjukkan bentuk sabuk yang memanjang ke arah utara. Selain itu hasil identifikasi elektrofasies menunjukkan adanya endapan point bar. Hal-hal tersebut mengindikasikan lingkungan pengendapan sungai berkelok.

\section{Analisis Fasies Arsitektural}

Channel sand terdiri dari litofasies Sf, Sm, Sc, dan Smmc. Struktur sedimen yang berkembang adalah silang-siur dan memiliki pola log yang blocky shape.
Point bar terdiri dari litofasies Sfwc, Sfbr. Struktur sedimen yang berkembang adalah silang-siur dan memiliki pola log bell shape. Crevasse splay terdiri dari litofasies Svf. Pola log yang terbentuk adalah funnel shape Overbank terdiri dari litofasies F dan Fr. Strukturnya masif, terdapat bioturbasi dan akar di beberapa tempat. Pola log yang terbentuk berupa garis datar yang konstan pada nilai sinar gamma yang tinggi.

\section{Analisis Tipe Batuan}

Proses ini menggunakan data analisis batuan inti dari sumur X-105, X-090, X104, dan X-153. Hasil perhitungan RQI

dan FZI menunjukkan adanya tiga tipe batuan. Tipe batuan 3 (RT 3) memiliki nilai FZI terburuk (0,08-0,93 mikrometer), tipe batuan 2 (RT 2) memiliki nilai FZI (0,97-1,56 mikrometer), dan tipe batuan 1 (RT 1) memiliki nilai FZI terbaik (1,58-3,96 mikrometer). Nilai FZI tersebut menunjukkan RT 1 memiliki nilai celah pori paling besar sehingga mampu melewatkan fluida paling baik. RT 3 memiliki nilai celah pori paling kecil sehingga melewatkan fluida paling buruk. Tabel 2, 3, 4, dan 5 menunjukkan pengolahan data untuk analisis batuan inti sumur X-105, X-090, X-104, dan X153.

Tabel 1. Analisis petrografi sumur X-090, X-104, dan X-105.

\begin{tabular}{|c|c|c|c|c|c|c|c|c|c|c|c|}
\hline No. & Sumur & Kedalaman (m) & Jenis Litologi & $\mathrm{Q}$ & $\mathrm{F}$ & $\mathrm{L}$ & Klasifikasi & Kebundaran & Sortasi & $\begin{array}{c}\text { Porositas } \\
\text { tampak (\%) }\end{array}$ & Tipe Porositas \\
\hline 1 & $\mathrm{X}-090$ & 987.96 & batupasir & $91.80 \%$ & $0.00 \%$ & $8.20 \%$ & quartzarenite & $\begin{array}{c}\text { menyudut tanggung- } \\
\text { membundar }\end{array}$ & sedang & 7 & antarbutir, pelarutan butir \\
\hline 2 & $\mathrm{X}-090$ & 998.83 & batupasir & $90.77 \%$ & $0.00 \%$ & $9.23 \%$ & quartzarenite & $\begin{array}{c}\text { menyudut tanggung- } \\
\text { membundar }\end{array}$ & sedang & 18 & antarbutir, pelarutan butir \\
\hline 3 & $\mathrm{X}-104$ & 885.70 & batulanau & $85.71 \%$ & $0.00 \%$ & $14.29 \%$ & sublitharenite & $\begin{array}{c}\text { menyudut-membundar } \\
\text { tanggung }\end{array}$ & sedang & 6 & antarbutir, pelarutan butir \\
\hline 4 & $\mathrm{X}-105$ & 913.22 & batupasir & $98.28 \%$ & $0.00 \%$ & $1.72 \%$ & quartzarenite & $\begin{array}{c}\text { menyudut tanggung- } \\
\text { membundar }\end{array}$ & baik & 18 & antarbutir, pelarutan butir \\
\hline 5 & $\mathrm{X}-105$ & 919.12 & batupasir & $93.85 \%$ & $0.00 \%$ & $6.15 \%$ & quartzarenite & $\begin{array}{c}\text { menyudut tanggung- } \\
\text { membundar }\end{array}$ & baik & 9 & antarbutir, pelarutan butir \\
\hline 6 & $\mathrm{X}-105$ & 922.57 & batupasir & $91.94 \%$ & $0.00 \%$ & $8.06 \%$ & quartzarenite & $\begin{array}{c}\text { menyudut tanggung- } \\
\text { membundar tanggung }\end{array}$ & baik & 23 & antarbutir, pelarutan butir \\
\hline 7 & $\mathrm{X}-105$ & 923.57 & batupasir & $89.23 \%$ & $3.08 \%$ & $7.69 \%$ & sublitharenite & $\begin{array}{c}\text { menyudut tanggung- } \\
\text { membundar }\end{array}$ & baik & 21 & antarbutir, pelarutan butir \\
\hline
\end{tabular}




\section{Analisis Tipe Batuan}

Proses ini menggunakan data analisis batuan inti dari sumur X-105, X-090, X104, dan X-153. Hasil perhitungan RQI

dan FZI menunjukkan adanya tiga tipe batuan. Tipe batuan 3 (RT 3) memiliki nilai FZI terburuk (0,08-0,93 mikrometer), tipe batuan 2 (RT 2) memiliki nilai FZI (0,97-1,56 mikrometer), dan tipe batuan 1 (RT 1) memiliki nilai FZI terbaik (1,58-3,96 mikrometer). Nilai FZI tersebut menunjukan RT 1 memiliki nilai celah pori paling besar sehingga mampu melewatkan fluida paling baik. RT 3 memiliki nilai celah pori paling kecil sehingga melewatkan fluida paling buruk. Tabel 2, 3, 4, dan 5 menunjukan pengolahan data untuk analisis batuan inti sumur X-105, X-090, X-104, dan X153.

Tabel 2. Perhitungan FZI sumur X-104.

\begin{tabular}{|c|c|c|c|r|r|r|r|c|}
\hline Sumur & $\begin{array}{c}\text { Kedalaman } \\
(\mathrm{m})\end{array}$ & $\begin{array}{c}\text { PERM } \\
\text { (mD) }\end{array}$ & $\begin{array}{c}\text { POROSTAS } \\
\text { (Fraksi) }\end{array}$ & $\begin{array}{c}\text { RQI } \\
\text { (mikrometer) }\end{array}$ & \multicolumn{1}{|c|}{$\phi_{z}$} & $\begin{array}{c}\text { FZl } \\
\text { (mikrometer) }\end{array}$ & DRT & $\begin{array}{c}\text { Tipe } \\
\text { Batuan }\end{array}$ \\
\hline X-104 & 887.3 & 3.66 & 0.182 & 0.140810324 & 0.22249389 & 0.63 & 10 & RT 3 \\
\hline X-104 & 887.9 & 23.6 & 0.205 & 0.33690598 & 0.25786164 & 1.31 & 11 & RT 2 \\
\hline X-104 & 887.6 & 41 & 0.227 & 0.421996305 & 0.29366106 & 1.44 & 11 & RT 2 \\
\hline
\end{tabular}

Tabel 3. Perhitungan FZI sumur X-090.

\begin{tabular}{|c|c|c|c|c|c|c|c|c|}
\hline Sumur & $\begin{array}{l}\text { Kedalaman } \\
(\mathrm{m})\end{array}$ & $\begin{array}{l}\text { PERM } \\
\text { (mD) }\end{array}$ & $\begin{array}{l}\text { POROSITAS } \\
\text { (Fraksi) }\end{array}$ & $\left|\begin{array}{c}\text { RQII } \\
\text { (mikrometer) }\end{array}\right|$ & $\phi_{2}$ & $\begin{array}{c}\text { Fll } \\
\text { (mikrometer) }\end{array}$ & DRT & $\begin{array}{l}\text { Tipe } \\
\text { Batuan }\end{array}$ \\
\hline X-090 & 989.5 & 11 & 0.26 & 0.20423930 & 0.35135135 & 0.58 & 10 & RT 3 \\
\hline X-090 & 985.2 & 14 & 0.255 & 0.23266099 & 0.34228188 & 0.68 & 10 & RT3 \\
\hline$X-090$ & 987.6 & 22 & 0.262 & 0.28773344 & 0.35501355 & 0.81 & 10 & RT3 \\
\hline X-090 & 998.9 & 25 & 0.252 & 0.31275149 & 0.33689840 & 0.93 & 10 & RT3 \\
\hline X-090 & 998.2 & 50 & 0.265 & 0.43131217 & 0.36054422 & 1.20 & 11 & RT2 \\
\hline X-090 & 988.5 & 35 & 0.222 & 0.39426405 & 0.28534704 & 1.38 & 11 & RT2 \\
\hline X-090 & 986.0 & 49 & 0.236 & 0.45245114 & 0.30890052 & 1.46 & 11 & RT2 \\
\hline X-090 & 993.5 & 12 & 0.145 & 0.28565134 & 0.16959064 & 1.68 & 12 & RT 1 \\
\hline X-090 & 990.2 & 114 & 0.222 & 0.71155027 & 0.28534704 & 2.49 & 12 & RT1 \\
\hline
\end{tabular}


Tabel 4. Perhitungan FZI sumur X-153.

\begin{tabular}{|c|c|c|c|r|r|r|r|c|}
\hline Sumur & $\begin{array}{c}\text { Kedalaman } \\
(\mathrm{m})\end{array}$ & $\begin{array}{c}\text { PERM } \\
(\mathrm{mD})\end{array}$ & $\begin{array}{c}\text { POROSITAS } \\
\text { (Fraksi) }\end{array}$ & $\begin{array}{c}\text { RQI } \\
\text { (mikrometer) }\end{array}$ & \multicolumn{1}{|c|}{$\Phi_{\mathbf{Z}}$} & $\begin{array}{c}\text { FZI } \\
\text { (mikrometer) }\end{array}$ & $\begin{array}{c}\text { Tipe } \\
\text { DRT }\end{array}$ \\
\hline X-153 & 846.76 & 0.02 & 0.136 & 0.01206355 & 0.15673800 & 0.08 & 5.00 & RT 3 \\
\hline X-153 & 843.08 & 0.32 & 0.169 & 0.04324611 & 0.20293516 & 0.21 & 8.00 & RT 3 \\
\hline X-153 & 846.03 & 0.03 & 0.067 & 0.02107430 & 0.07135205 & 0.30 & 8.00 & RT 3 \\
\hline X-153 & 849.8 & 3.10 & 0.167 & 0.13512409 & 0.20105693 & 0.67 & 10.00 & RT 3 \\
\hline X-153 & 847.69 & 15.00 & 0.253 & 0.24182481 & 0.33850890 & 0.71 & 10.00 & RT 3 \\
\hline X-153 & 848.29 & 42.00 & 0.283 & 0.38279673 & 0.39392250 & 0.97 & 11.00 & RT 2 \\
\hline X-153 & 848.87 & 56.00 & 0.288 & 0.43823266 & 0.40350877 & 1.09 & 11.00 & RT 2 \\
\hline X-153 & 848.66 & 91.00 & 0.289 & 0.55738047 & 0.40607424 & 1.37 & 11.00 & RT 2 \\
\hline X-153 & 849.29 & 180.00 & 0.248 & 0.84577047 & 0.32996409 & 2.56 & 12.00 & RT 1 \\
\hline
\end{tabular}

Tabel 5. Perhitungan FZI sumur X-105.

\begin{tabular}{|c|c|c|c|c|c|c|c|c|}
\hline Sumur & $\begin{array}{c}\text { Kedalaman } \\
(\mathrm{m})\end{array}$ & $\begin{array}{l}\text { PERM } \\
\text { (mD) }\end{array}$ & $\begin{array}{c}\text { POROSTIAS } \\
\text { (Fraksi) }\end{array}$ & $\begin{array}{c}\text { RQI } \\
\text { (mikrometer) }\end{array}$ & $\Phi \mathbf{z}$ & $\begin{array}{c}\text { FZl } \\
\text { (mikrometer) }\end{array}$ & DRT & $\begin{array}{l}\text { Tipe } \\
\text { Batuan }\end{array}$ \\
\hline$X-105$ & 920.0 & 0.01 & 0.088 & 0.01058494 & 0.09649123 & 0.11 & 6 & RT 3 \\
\hline$X-105$ & 915.0 & 0.06 & 0.111 & 0.02311700 & 0.12447993 & 0.19 & 7 & RT 3 \\
\hline$X-105$ & 913.0 & 0.01 & 0.056 & 0.01323352 & 0.05965879 & 0.22 & 8 & RT 3 \\
\hline$X-105$ & 919.7 & 0.01 & 0.051 & 0.01389054 & 0.05385183 & 0.26 & 8 & RT 3 \\
\hline$X-105$ & 919.3 & 0.01 & 0.046 & 0.01464033 & 0.04821803 & 0.30 & 8 & RT 3 \\
\hline$X-105$ & 911.0 & 0.05 & 0.071 & 0.02635029 & 0.07642626 & 0.34 & 8 & RT 3 \\
\hline$X-105$ & 911.3 & 2.52 & 0.220 & 0.10639290 & 0.28122998 & 0.38 & 9 & RT 3 \\
\hline$X-105$ & 915.3 & 0.15 & 0.093 & 0.03983523 & 0.10277900 & 0.39 & 9 & RT 3 \\
\hline$X-105$ & 919.0 & 0.01 & 0.039 & 0.01596152 & 0.04025798 & 0.40 & 9 & RT 3 \\
\hline$X-105$ & 920.3 & 0.17 & 0.094 & 0.04213744 & 0.10424028 & 0.40 & 9 & RT 3 \\
\hline$X-105$ & 912.7 & 0.45 & 0.125 & 0.05962503 & 0.14259598 & 0.42 & 9 & RT 3 \\
\hline$X-105$ & 922.7 & 0.58 & 0.122 & 0.06860496 & 0.13830393 & 0.50 & 9 & RT 3 \\
\hline$X-105$ & 914.7 & 0.02 & 0.041 & 0.02190402 & 0.04286161 & 0.51 & 9 & RT 3 \\
\hline$X-105$ & 912.0 & 1.48 & 0.151 & 0.09823915 & 0.17813384 & 0.55 & 9 & RT 3 \\
\hline $\mathrm{X}-105$ & 912.3 & 0.92 & 0.127 & 0.08441300 & 0.14586914 & 0.58 & 10 & RT 3 \\
\hline$X-105$ & 911.7 & 12.00 & 0.261 & 0.21299356 & 0.35281385 & 0.60 & 10 & RT 3 \\
\hline$X-105$ & 916.0 & 6.84 & 0.217 & 0.17616833 & 0.27762872 & 0.63 & 10 & RT 3 \\
\hline$X-105$ & 921.7 & 33.00 & 0.280 & 0.34064154 & 0.38966092 & 0.87 & 10 & RT 3 \\
\hline$X-105$ & 920.7 & 25.00 & 0.254 & 0.31127275 & 0.34120172 & 0.91 & 10 & RT 3 \\
\hline$X-105$ & 918.7 & 0.38 & 0.068 & 0.07439215 & 0.07261611 & 1.02 & 11 & RT 2 \\
\hline$X-105$ & 916.7 & 73.00 & 0.285 & 0.50227342 & 0.39918847 & 1.26 & 11 & RT 2 \\
\hline$X-105$ & 915.7 & 64.00 & 0.275 & 0.47884551 & 0.37969095 & 1.26 & 11 & RT 2 \\
\hline$X-105$ & 917.3 & 76.00 & 0.273 & 0.52352472 & 0.37627305 & 1.39 & 11 & RT 2 \\
\hline$X-105$ & 918.3 & 0.71 & 0.067 & 0.10221660 & 0.07181136 & 1.42 & 11 & RT 2 \\
\hline$X-105$ & 917.7 & 106.00 & 0.281 & 0.60985898 & 0.39082058 & 1.56 & 11 & RT 2 \\
\hline$X-105$ & 917.0 & 74.00 & 0.254 & 0.53648369 & 0.33958473 & 1.58 & 12 & RT 1 \\
\hline$X-105$ & 921.3 & 108.00 & 0.280 & 0.61624374 & 0.38966092 & 1.58 & 12 & RT 1 \\
\hline$X-105$ & 922.0 & 100.00 & 0.274 & 0.60030450 & 0.37665198 & 1.59 & 12 & RT 1 \\
\hline$X-105$ & 916.3 & 124.00 & 0.280 & 0.66055111 & 0.38927480 & 1.70 & 12 & RT 1 \\
\hline$X-105$ & 921.0 & 167.00 & 0.282 & 0.76358175 & 0.39353400 & 1.94 & 12 & RT 1 \\
\hline$X-105$ & 922.3 & 162.00 & 0.257 & 0.78865969 & 0.34553283 & 2.28 & 12 & RT 1 \\
\hline$X-105$ & 918.0 & 229.00 & 0.281 & 0.89590616 & 0.39140114 & 2.29 & 12 & RT 1 \\
\hline$X-105$ & 910.6 & 1.07 & 0.040 & 0.16322021 & 0.04123282 & 3.96 & 13 & RT 1 \\
\hline
\end{tabular}




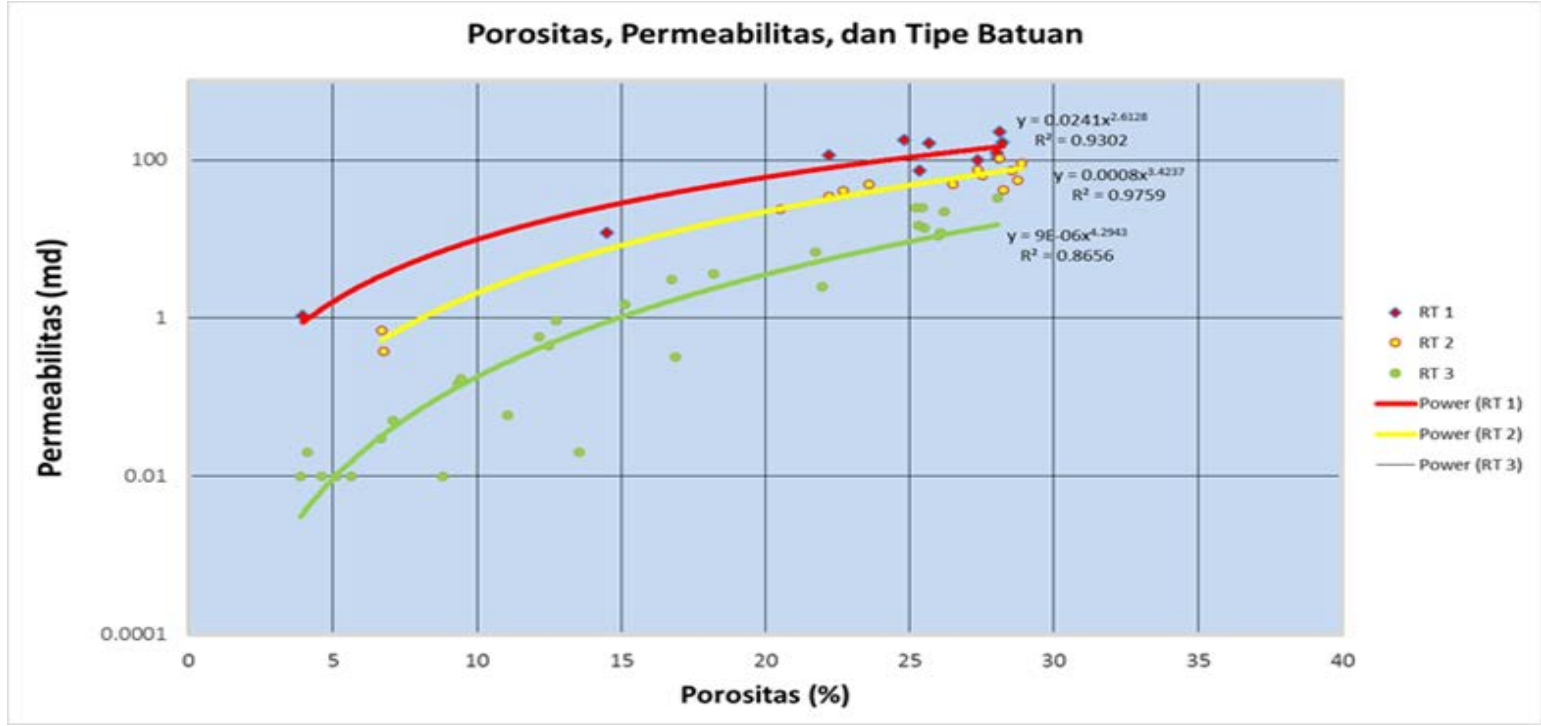

Gambar 2. Plot porositas vs. permeabilitas.

Setiap tipe batuan memiliki hubungan porositas dan permeabilitas masingmasing yang ditunjukkan melalui persamaan garis. Batuan dengan kemiripan nilai FZI berada di sekitar kurva tipe batuan tertentu, seperti ditunjukkan Gambar 2. Ketiga tipe batuan dan persamaan garisnya memiliki nilai koefisien korelasi $\left(\mathrm{R}^{2}\right)$ yang cukup baik. RT 1 memiliki $\mathrm{R}^{2}$ sebesar 0,93. RT 2 memiliki $\mathrm{R}^{2}$ sebesar 0,98. RT 3 memiliki $\mathrm{R}^{2}$ sebesar 0,87.

Validasi jumlah tipe batuan yang telah diidentifikasi menggunakan dua cara, yaitu dengan mercury injection capillary pressure (MICP) dan menggunakan plot silang antara normalized porosity $(\phi \mathrm{z})$ terhadap RQI.

Data MICP menunjukan adanya perbedaan profil tekanan pada lima sampel yang diuji. Perbedaan tekanan adalah indikasi adanya beberapa tipe batuan. MICP menunjukkan bahwa RT 1 memiliki sifat aliran paling baik dan RT 3 memiliki sifat aliran paling buruk.

Plot silang ( $\phi \mathrm{z})$-RQI digunakan untuk mengamati jumlah garis kemiringan yang sejajar. Sampel yang berada di dalam satu tipe batuan cenderung tersebar berdekatan dengan garis kemiringannya.
Jumlah garis kemiringan yang ditemukan berjumlah tiga buah sesuai dengan jumlah tipe batuan yang berhasil diidentifikasi.

\section{Hubungan Tipe Batuan terhadap Fasies Arsitektural dan Litofasies}

Tipe batuan pada Lapisan D Formasi Tanjung memiliki hubungan dengan fasies arsitektural yang telah dianalisis. Satu fasies arsitektural dapat memiliki satu atau lebih tipe batuan di dalamnya.

RT 1 memiliki sifat aliran paling baik, porositas 3,96-28.24\%, permeabilitas 1,07-229 md. RT 1 terdiri dari litofasies Smwc dan Sc dan hanya terdapat pada channel sand.

RT 2 memiliki sifat aliran sedang, porositas 6,7-28,88\%, permeabilitas 0,38-106 md. RT 2 terdiri dari litofasies Sfwc dan Fr dan terdapat pada fasies arsitektural channel sand, point bar, dan overbank.

RT 3 memiliki sifat aliran paling buruk, porositas 3,87-28,04\% dengan permeabilitas 0,01-33 md. RT 3 terdiri dari litofasies F, Sfbr, Sf, Svf, dan Smmc dan terdapat pada fasies arsitektural channel sand, point bar, overbank, dan crevasse splay. 
Hubungan Tipe Batuan terhadap Sayatan Tipis

Sampel sayatan tipis yang tergolong RT 1 berjumlah 3 buah dan termasuk ke dalam klasifikasi quartzarenite dan sublitharenite dengan litofasies Smwc dan Sc. Fasies arsitektural berupa channel sand.

Sampel sayatan tipis yang tergolong RT 3 berjumlah empat buah dan termasuk ke dalam klasifikasi quartzarenite dan sublitharenite dengan litofasies Sf, Sfbr, $\mathrm{f}$, dan Sf. Fasies arsitektural berupa channel sand, point bar, dan overbank.

RT 2 tidak terdapat pada semua sampel sayatan tipis Klasifikasi quartzarenite terdapat pada RT 1 dan RT 3, begitu juga dengan sublitharenite. Hal ini menunjukkan jenis butiran bukan merupakan faktor utama pembentuk tipe batuan. Ukuran celah pori merupakan faktor terpenting sebagai pembeda dari tipe batuan satu dengan yang lainnya.

\section{Prediksi Tipe Batuan}

Batuan inti pada sumur X-105, X-090, dan X-104 tidak mencakup seluruh interval sehingga diperlukan metode untuk memprediksi tipe batuan pada interval tanpa batuan inti. Metode tersebut juga diharapkan dapat memprediksi tipe batuan pada sumur tanpa batuan inti.

Multi-resolution graph-based clustering (MRGC) adalah metode pengenalan pola titik multidimensi berdasarkan representasi data grafik. Struktur yang terdapat di dalam data dilakukan analisis sehingga dapat membentuk kelompok data alami yang dapat memiliki perbedaan ukuran, bentuk, dan kerapatan. MRGC secara otomatis menentukan jumlah cluster secara optimal, sehingga tingkat ketelitian yang diperlukan dapat dikontrol (Ye dan Rabiller, 2000).

Pengaplikasian metode MRGC memerlukan data acuan sebagai referensi. Data input log talikawat yang digunakan adalah log sinar gamma, neutron, dan resistivitas karena tersedia di sumur-sumur lainnya. Sumur yang digunakan dalam prediksi sebaran tipe batuan adalah sumur X-105. Hasil sebaran secara vertikal pada sumur $\mathrm{X}$ 105 menunjukkan kecocokan antara tipe batuan hasil analisis dengan prediksi vertikal menggunakan metode MRGC. Gambar 3 menunjukkan prediksi tipe batuan menggunakan metode MRGC.

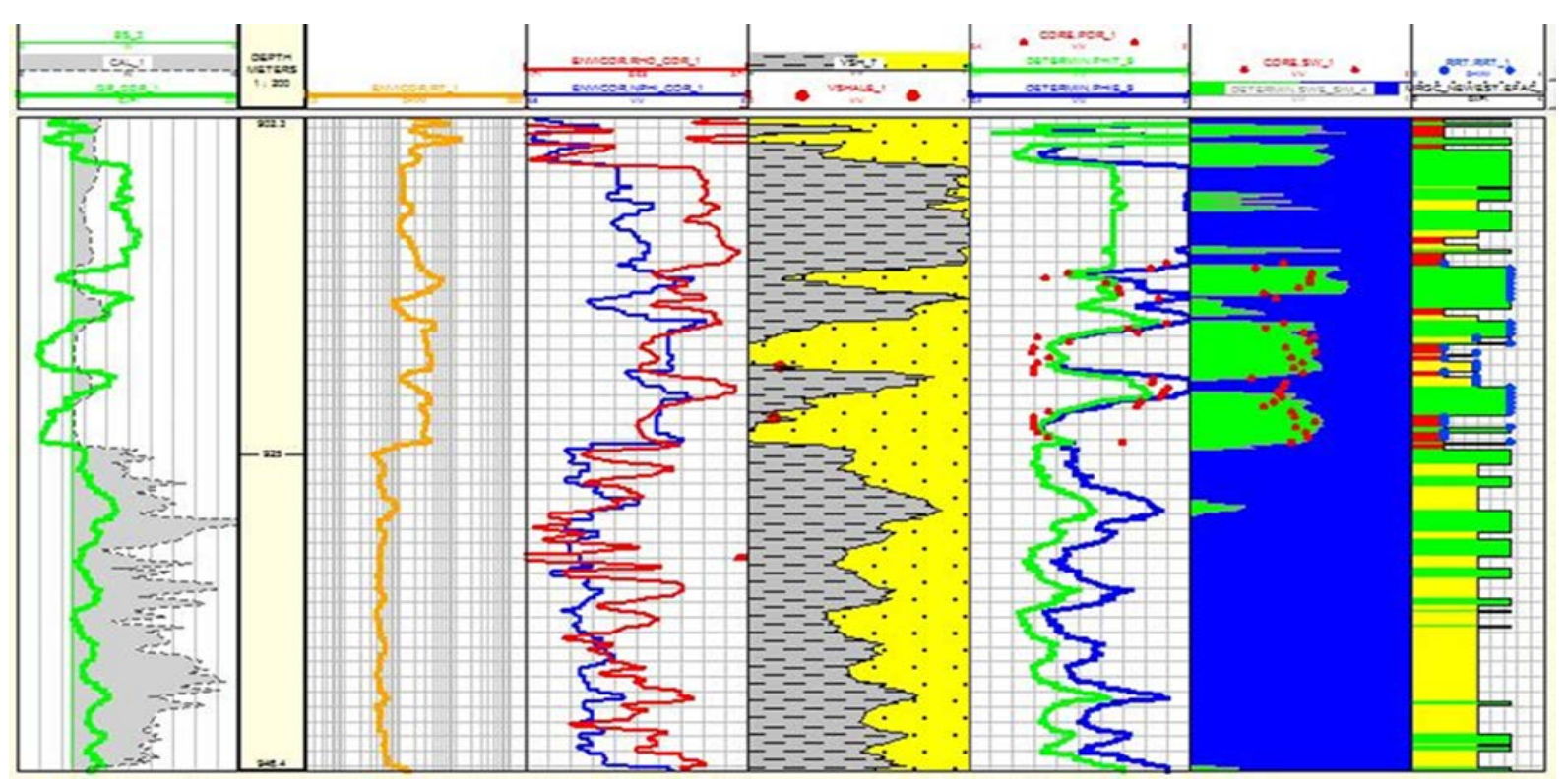

Gambar 3. Prediksi tipe batuan dan validasi sumur X-105. 


\section{PEMODELAN RESERVOIR}

Pemodelan reservoir memperhatikan aspek spasial dan statistik (geostatistik) yang baik dalam penyebaran data fasies atau petrofisika pada sumur (Deutcsh, 2002).

Pemodelan fasies dilakukan berdasarkan analisis data batuan inti dan log yang telah dilakukan sebelumnya. Pemodelan fasies berfungsi untuk mengontrol sebaran pada tipe batuan. Penyebaran fasies dari data sumur menggunakan metode truncated gaussian simulation (TGS) karena baik dalam memodelkan unit-unit reservoir yang memiliki urutan secara alami (Matheron dkk., 1997).
Gambar 4 menunjukkan hasil pemodelan fasies.

Pemodelan tipe batuan dikontrol oleh fasies arsitektural dengan menggunakan metode sequential indicator simulation (SIS) karena mampu mengintegrasikan berbagai macam data (Deutsch, 2002). Metode TGS tidak cocok digunakan dalam pemodelan tipe batuan karena tidak realistis dalam memodelkan data yang sebarannya tidak berurutan (Syversveen, 2007). Gambar 5 menunjukkan hasil pemodelan tipe batuan.

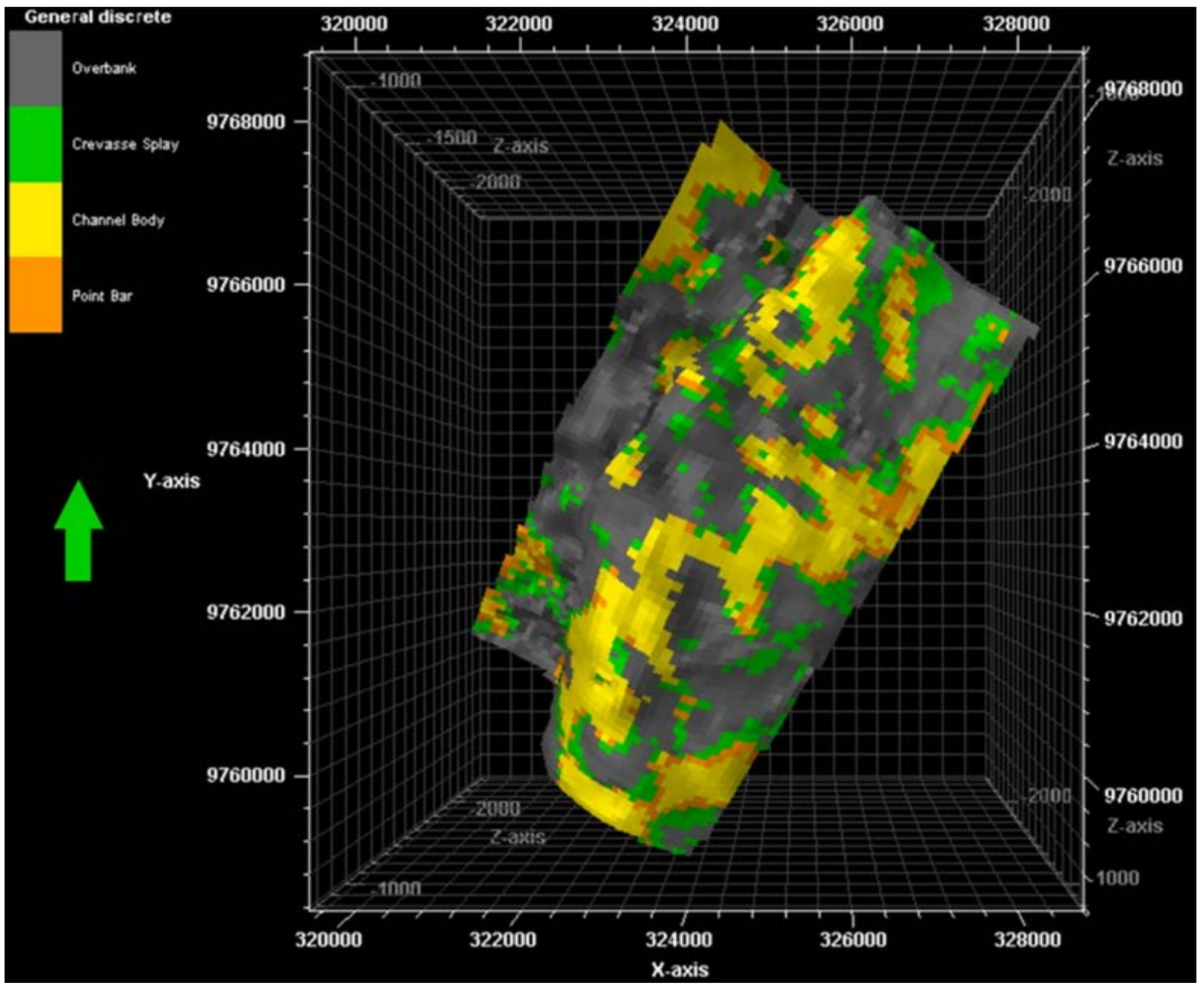

Gambar 4. Pemodelan fasies. 


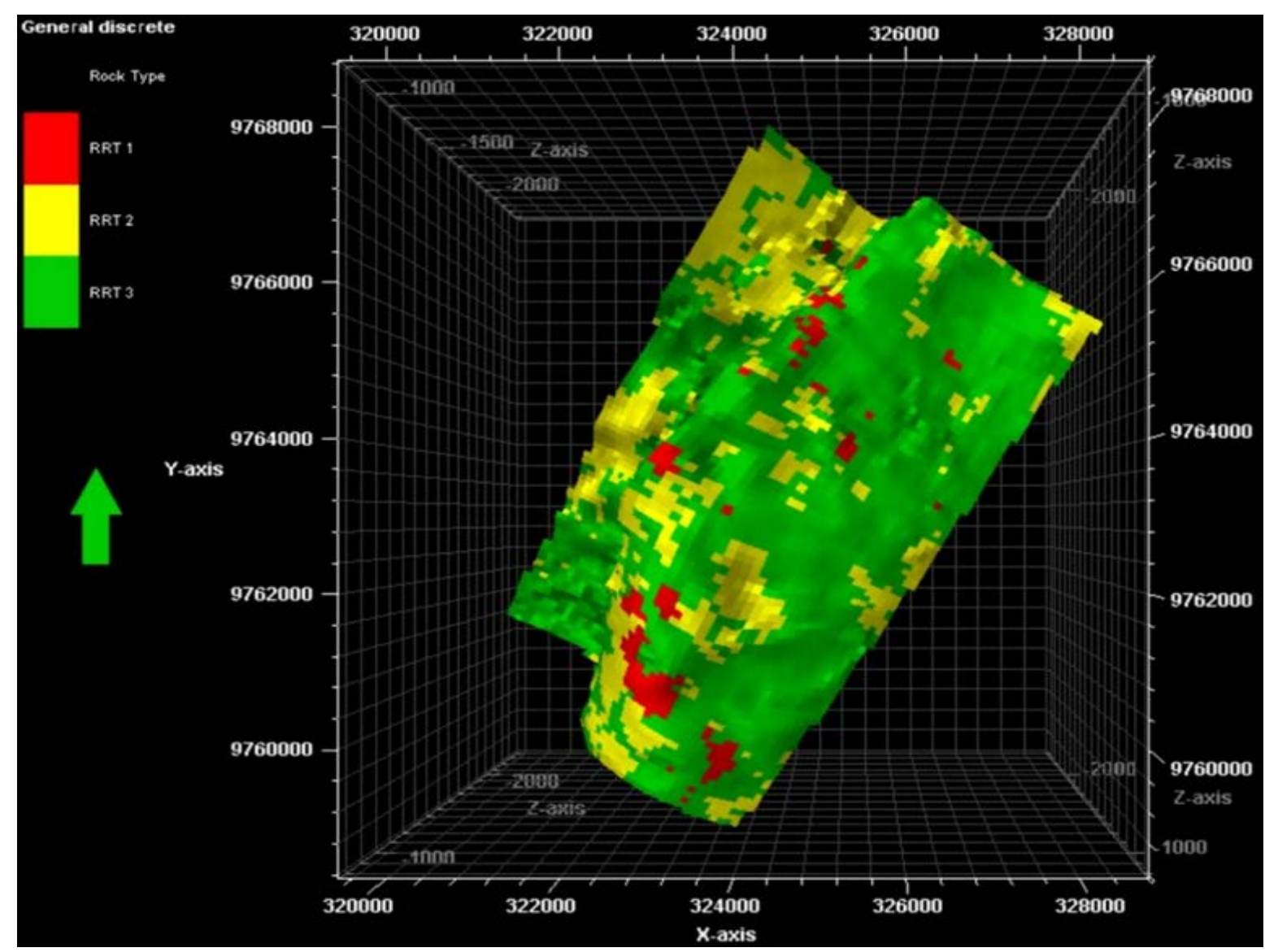

Gambar 5. Pemodelan tipe batuan.

Pemodelan porositas menggunakan sequential gaussian simulation (SGS) yang dikontrol oleh analisis variogram. Sebaran porositas efektif dengan nilai baik berada pada fasies channel sand. Fasies point bar dan crevasse splay memiliki porositas yang cukup baik, Fasies overbank memiliki porositas paling buruk.

Pemodelan permeabilitas menggunakan formula transformasi nilai porositaspermeabilitas hasil analisis berdasarkan masing-masing tipe batuan. Nilai permeabilitas paling baik berada pada daerah dengan nilai porositas yang baik dan memiliki tipe batuan RT 1 . Sementara nilai permeabilitas paling buruk berada pada daerah dengan nilai porositas rendah dan memiliki tipe batuan RT 3.

\section{KESIMPULAN}

Lapisan D adalah reservoir silisikastik yang diendapkan pada lingkungan sungai berkelok dan memiliki 9 litofasies: F, Fr, Svf, Sf, Sfbr, Sfwc, Smwc, Smmc, dan Sc. Kesembilan litofasies dikelompokkan ke dalam fasies arsitektural channel sand, point bar, crevasse splay, dan overbank. Porositas yang terbentuk adalah antarbutir dan pelarutan. Diagenesis mengontrol kualitas tipe batuan. Berdasarkan metode FZI, terdapat tiga tipe batuan: RT 1 memiliki porositas 3,96-28,24\% dan permeabilitas 1,07-229 md, dengan fasies arsitektural channel sand, RT 2 memiliki porositas $6,7-28,88 \%$ dan permeabilitas 0,38-106 md, dengan fasies arsitektural berupa channel sand, point bar, dan overbank, dan RT 3 yang memiliki porositas 3,87-28,04\% dan permeabilitas 0,01-33 md, dengan fasies arsitektural berupa channel sand, point bar, crevasse splay, dan overbank. 
DAFTAR PUSTAKA

Abbaszadeh, M., Fuji, H., dan Fujimoto, F. (1996). Permeability prediction by hydraulic flow unit - theory and applications, SPE Formation Evaluation Journal, Ho Chi Minh, 263-271.

Amaefule, O.J., Altunbay, M., Tiab, D., Kersey, D.G., dan Keelan, D.K. (1993). Enhanced reservoir description: using core and log data to identify hydraulic (flow) units and predict permeability in uncored intervals/wells, SPE 26436, 205-217.

Deutcsh, C.V. (2002). Geostatistical Reservoir Modelling, Oxford University Press, New Your, 376 hal.

Kusuma, I. dan Darin, T. (1989). The hydrocarbon potential of the Lower Tanjung Formation, Barito Basin, SE Kalimantan, Proceedings Indonesian Petroleum Association, $18^{\text {th }} \quad$ Annual Convention, 107-138.

Matheron, G., Beucher, H., de Foucquet, H., Galli, A., Guerrliot, D., dan Ravenne, C. (1987). Conditional simulation of the geometry of fluvio-deltaic reservoirs, SPE Annual Technical Conference and Exhibition, SPE 16753.

Satyana, A.H., Silitonga, P.D. (1994). Tectonic reversal in East Barito Basin, South Kalimantan: consideration of the types of inversion structures and petroleum system significance, Proceedings Indonesian Petroleum Association, 23th Annual Convention, 57-74.

Syversveen, A.R. (2007). Modeling atolls by truncated gaussian simulation, EAGE, Petroleum Geostatistics Conference, 5 hal.

Walker, R. dan James, N. (1992). Facies model: response to sea level change, Geological Association of Canada, 409 hal.
Ye, S.J. dan Rabiller, P. (2000). A new tool for electrofacies analysis: Multi-resolution graph-based clustering, SPWLA $41^{\text {st }}$ Annual Logging Symposium Transaction. 